\title{
Investigation of Principal Leadership Based on Pesantren: Descriptive Study about Implementation of Human Resources Empowerment Models Based on Soft System Methodology
}

\author{
Imam Gunawan \\ Department of Educational Administration \\ Universitas Negeri Malang, Indonesia \\ imam.gunawan.fip@um.ac.id
}

\author{
Desi Eri Kusumaningrum \\ Department of Educational Administration \\ Universitas Negeri Malang, Indonesia \\ desi.eri.fip@um.ac.id
}

\author{
Raden Bambang Sumarsono \\ Department of Educational Administration \\ Universitas Negeri Malang, Indonesia \\ raden.bambang.fip@um.ac.id
}

\begin{abstract}
A quality school can certainly be led by a school principal with good and professional leadership. The headmaster's leadership will affect all aspects of the administration of education in the school. Therefore, there needs to be an ongoing effort to empower and strengthen the principal's leadership. The Soft System Methodology (SSM) approach is an alternative model that can be used to strengthen the principal's leadership. The purpose of the study was to measure the leadership of the principal. The variable is a variable that is influenced by the implementation of the SSM-based human resource empowerment model. This study uses a preexperimental design type one-shot case study. The number of respondents in this study were 84 people, consisting of school principals, teachers, and staff. The study was conducted in three pesantren-based schools in East Java, Indonesia. The results of this study indicate that the application of the SSM-based human resource empowerment model is quite effective in influencing the learning leadership variable; change leadership; and spiritual leadership.
\end{abstract}

Keywords: empowerment of learning leadership, change leadership, spiritual leadership, soft system methodology

\section{INTRODUCTION}

Leadership is the most important variable in the administration of education in schools. The person who plays the role of leader in the school is the principal. Therefore, the principal has an important role in the organization of the school. The direction of the school is determined by the leadership of the principal. Professional school principals will have good teachers and students too, and thus the school will become a quality school. Referring to this mindset, there needs to be a massive effort to strengthen the principal's leadership. Empowering the principal with the soft system methodology (SSM) approach is a real effort to strengthen the principal's leadership.

The adoption of the SSM approach to strengthen the principal's leadership has an impact on better school performance (Kusumaningrum, et al., 2018b). Empowerment of school principals with the SSM approach allows principals: (1) understand and be able to analyze situations and problems faced by schools appropriately; (2) able to analyze the relationships and roles of related parties that can help improve the quality of school education; and (3) able to analyze the social roles of the parties involved in the administration of school education (Rukmana, 2009; Gunawan, 2015).

Principal's leadership has dimensions that can be further developed for the benefit of school development. The leadership dimensions are: learning leadership; change leadership; and spiritual leadership. Learning leadership is leadership that pays close attention to aspects of the school associated with learning activities. An aspect related to learning leadership is the process of improving the quality of learning activities. Change leadership is leadership that is quick to respond to changes that occur in society and these changes become elements that can affect school organizations.

The principal has a program design that is able to resonate with these changes. These changes include changes that occur in the fields of technology, science, social, and culture. Spiritual leadership are leadership traits based on the breath that humans as leaders are given the mandate of God to manage life (Sultoni, et al., 2018). Spiritual leadership has the essence that is important in growing the spirit of work, commitment, and organizational loyalty. The purpose of this study is to measure the effectiveness of school principals' leadership after schools apply the SSM-based human resource empowerment model.

\section{METHOD}

This research is a third-year research with the research title: Development of Pesantren-Based Middle School Human Resource Empowerment Model with Soft System Methodology Approach. This third-year research measures the variables that are influenced by the application of the SSM-based human resource empowerment model. The measured variables are: learning leadership; change leadership; and spiritual leadership. The design of this study was a pre-experimental type of oneshot case study (Figure 1).

In the range of 2017 to 2018 , the school applies the SSM-based human resource empowerment model, and in 2019 the effectiveness of the principal's leadership is measured. The instrument used to measure learning leadership variables; change leadership; and spiritual leadership is a questionnaire. 
\begin{tabular}{ll|l}
$\mathbf{X}$ & $\mathbf{O}$ & $\begin{array}{l}\mathrm{X}=\text { Treatment given (application of SSM model) } \\
\mathrm{O}=\text { Observation (measurement of variables) }\end{array}$
\end{tabular}

Figure 1

One-Shot Case Study

The number of respondents in this study were 84 people, consisting of school principals, teachers, and staff (Table 1). The study was conducted in three pesantrenbased schools in East Java, Indonesia, namely: SMP Insan Terpadu Probolinggo; SMP Assa'adah Gresik; and SMP
An Nur Bululawang Malang. Analysis of the data used is descriptive statistics by calculating: average, standard deviation, maximum score, minimum score, range, and interval.

From the results of these calculations, then the data for each variable is presented in the form of a frequency distribution table. Determination of the effectiveness of the principal's leadership by applying the SSM approach is to determine the average score produced on each variable.

Table 1

Research Respondents

\begin{tabular}{|c|l|c|c|c|c|}
\hline No & School & Principal & Teacher & Staff & Total \\
\hline 1 & SMP Insan Terpadu Probolinggo & 1 person & 17 person & 4 person & $\mathbf{2 2}$ person \\
\hline 2 & SMP Assa'adah Gresik & 1 person & 20 person & 10 person & $\mathbf{3 1}$ person \\
\hline 3 & SMP An Nur Bululawang Malang & 1 person & 20 person & 10 person & $\mathbf{3 1}$ person \\
\hline & Total & $\mathbf{3}$ person & $\mathbf{5 7}$ person & $\mathbf{2 4}$ person & $\mathbf{8 4}$ person \\
\hline
\end{tabular}

\section{RESULTS}

Based on the results of the data description of the learning leadership variables known: mean 61.79; standard deviation 6.34; maximum score of 72 ; minimum score of 47; range 25; and interval 6 . The description of the frequency of learning leadership variables is presented in Table 2. The results of the calculation of the average learning leadership variable were 61.79 and included in the category of quite effective. It was concluded that the application of the SSM-based human resource empowerment model was quite effective in influencing the learning leadership variable.

Table 2

Frequency Distribution of Learning Leadership Variables

\begin{tabular}{|l|c|c|c|}
\hline Category & Interval & $\mathbf{f}$ & \% \\
\hline Very low & $47-52$ & 8 & 9,52 \\
\hline Low & $53-58$ & 20 & 23,81 \\
\hline Adequate & $59-64$ & 24 & 28,57 \\
\hline High & $65-69$ & 21 & 25,00 \\
\hline Very high & $70-75$ & 11 & 13,10 \\
\hline \multicolumn{4}{|c|}{ Total } \\
\hline
\end{tabular}

Based on the results of the data description of change leadership variables known: mean 52.43; standard deviation 6.23; maximum score of 64; minimum score of 27; range 37; and interval 9. The description of the frequency of change leadership variables is presented in Table 3. The results of the calculation of the average change leadership variable are 52.43 and are included in the quite effective category. It was concluded that the application of the SSM-based human resource empowerment model was quite effective in influencing the leadership variable of change.

Table 3

Frequency Distribution of Change Leadership Variables

\begin{tabular}{|l|c|c|c|}
\hline \multicolumn{1}{|c|}{ Category } & Interval & $\mathbf{f}$ & $\boldsymbol{\%}$ \\
\hline Very low & $27-35$ & 1 & 1,19 \\
\hline Low & $36-44$ & 4 & 4,76 \\
\hline Adequate & $45-53$ & 44 & 52,38 \\
\hline High & $54-62$ & 30 & 35,71 \\
\hline Very high & $63-71$ & 5 & 5,95 \\
\hline \multicolumn{4}{|c|}{ Total } \\
\hline
\end{tabular}

Based on the results of the description of the spiritual leadership variables data are known: mean 49.57; standard deviation 6.05 ; maximum score of 60 ; minimum score of 27; range 33; and interval 8 . The description of the frequency of spiritual leadership variables is presented in Table 4. The average calculation result of the spiritual leadership variable is 49.57 and is included in the quite effective category. It was concluded that the application of the SSM-based human resource empowerment model was quite effective in influencing the spiritual leadership variable.

Table 4

Frequency Distribution of Spiritual Leadership Variables

\begin{tabular}{|c|c|c|c|}
\hline Category & Interval & f & $\%$ \\
\hline Very low & $27-34$ & 1 & 1,19 \\
\hline Low & $34-41$ & 4 & 4,76 \\
\hline Adequate & $42-49$ & 40 & 47,62 \\
\hline High & $50-57$ & 31 & 36,90 \\
\hline Very high & $58-65$ & 8 & 9,52 \\
\hline \multicolumn{2}{|c|}{ Total } & 84 & 100 \\
\hline
\end{tabular}

\section{DISCUSSION}

This study concludes that the application of the SSM-based human resource empowerment model is quite effective in influencing the learning leadership variable; change leadership; and spiritual leadership. This study is in line with the results of Kusumaningrum, et al. (2018a) which concluded that the principal will be more empowered when the school adopts the SSM-based human resource empowerment model. Empowering the principal requires the ability of the school to treat the principal as the key person leading the school and not as a mere bureaucrat (Sudayat, 2014; Gunawan, et al., 2018). Principal empowerment is related to the leadership and creativity possessed by the principal (Özarall, 2015; Gunawan, 2017). Therefore, the principal must be able to empower himself for the progress of the school (Kusumaningrum, et al., 2018a; Sultoni, et al., 2018; Pertiwi, et al., 2018).

The main activity carried out by schools is learning activities. Learning leadership becomes an important leadership model for school principals to apply. Learning leadership is an action taken with the intention of developing a productive and satisfying work environment 
for teachers, and in the end is able to create conditions for increasing student learning (Eggen and Kauchak, 2014). Learning leadership is an effort to lead teachers to teach better, which in turn can improve student learning achievement (Daresh and Playco, 1995). The principal provides support for learning, for example the principal supports that teaching that focuses on the interests of student learning must be a priority (Patterson, 1993).

The school principal monitors the teaching and learning process, so that he understands more deeply and is aware of what is happening inside the school. The success of effective school principals as learning leaders are: (1) as a provider of resources, which is able to manage time, classroom conditions, and motivate teachers; (2) as an instructional source, namely promoting effective classroom conditions to support learning outcomes; (3) as a communicator, which is able to convey vision and understand school goals to teachers; and (4) its presence is meaningful, i.e. able to interact and influence all school members (Jenkins, 2009). Principal's leadership is an important factor in improving the quality of school education.

Change leadership can enhance team reflection on the results of their performance and focus on efforts to correct mistakes and efforts to develop the organization (Kalmanovich-Cohen, et al., 2018). Change leadership is the behavior of the principal as a leader who is more focused on mobilizing education and education personnel in making ongoing changes to improve the quality of learning. School principals who are professional and implement leadership change significantly affect teacher teaching performance (Taylor, et al., 2011). Wills (2016) based on the results of his research concluded that leadership change has a direct influence on school performance and teacher teaching performance. Change leadership capacity will determine the level of performance of subordinates (Katkat, 2014). The change leadership capacity of school principals also determines the performance of teachers and staff (Gunawan, et al., 2018).

Leavitt (2016) suggests that in order to implement organizational change there are four types of strategies that can be chosen, namely: (1) changes in organizational structure; (2) technological change; (3) change of assignment; and (4) human changes. A series of school principals' actions as leaders of change in the form of: (1) looking at the future and designing changes to anticipate the future (visionary); (2) inspire teachers to look to the future to make changes; (3) establish strategic steps for change; (4) implementing changes; and (5) evaluating changes and planning follow-up (Bafadal, et al., 2016).

Leadership spirituality as a combination of values, attitudes, and behaviors that are needed to motivate themselves and others intrinsically, so they have spiritual leadership as a call of duty (Frey, 2003). Spiritual leadership aims to motivate and inspire employees through the creation of a vision and culture that is based on altruistic values to produce a workforce that has organizational commitment and productivity (Fry et al., 2005). Spiritual values that can be done by the principal are honesty, discipline, and responsibility. Spiritual values will have an impact on the morale of teachers and staff in schools. These values need to be internalized into the culture and climate of school organizations (Kusumaningrum, et al., 2019), so principals must transform these values to all citizens in the school.

Spiritual leadership is operationalized by Bafadal, et al. (2018) into a series of actions by the school principal in the form of: (1) hard work based on responsibility (2) discipline; (3) honesty; (4) role models; and (5) always be grateful in every success and failure based on sincerity and patience. Polat (2011) which states spiritual leadership has a significant influence on the performance of the bahawan. Spiritual leadership influences subordinates 'assessment of leadership style and can improve subordinates' performance (Yi-Chen and Li, 2013). Spiritual leadership will be more meaningful when accompanied by values and attitudes that originate from universal wisdoms (Whittington, et al., 2005). The purpose of spiritual leadership is to create a vision and alignment of the values of all empowered team members, and at the individual level, ultimately to foster higher commitment, organizational productivity, and member welfare (Fry, 2003; Fry et al., 2005).

\section{CONCLUSION}

This study concludes that the application of the SSM-based human resource empowerment model is quite effective in influencing the learning leadership variable; change leadership; and spiritual leadership. The results of this study reinforce the assumption that the application of the SSM-based human resource empowerment model is able to increase the leadership capacity and capability of school principals. The principal has a strategic role in the administration of education in schools. The principal is the main actor in improving the quality of school education.

\section{REFERENCES}

[1] Bafadal, I., Juharyanto, Nurabadi, A., \& Gunawan, I. 2018. Pengaruh Kepemimpinan Pembelajaran, Kepemimpinan Perubahan, dan Kepemimpinan Spiritual yang Diterapkan di Sekolah terhadap Kualitas Kinerja dan Hasil Belajar (Output) pada Sekolah Dasar di Malang Raya. Research report. Malang: LP2M Universitas Negeri Malang.

[2] Bafadal, I., Sobri, A. Y., \& Nurabadi, A. 2016. Kepemimpinan Pembelajaran dalam Implementasi Kurikulum di Sekolah Unggul. Research report. Malang: Fakultas Ilmu Pendidikan Universitas Negeri Malang.

[3] Daresh, J. C., \& Playco, M. A. 1995. The Arrival of the New Principal: Reactions of Staff. Theory into Practice, 23, 168-173.

[4] Eggen, P., \& Kauchak, D. 2014. Educational Psychology: Windows on Classrooms. New York: Pearson Prentice Hall, Upper Saddle River.

[5] Fry, L. W. 2003. Toward a Theory of Spiritual Leadership. The Leadership Quarterly, 14(6), 693-727.

[6] Fry, L. W., Vitucci, S., \& Cedillo, M. 2005. Spiritual Leadership and Army Transformation: Theory, Measurement, and Establishing a Baseline. The Leadership Quarterly, 16(5), 835-862.

[7] Gunawan, I. 2015. Penumbuhan Budi Pekerti Peserta Didik Melalui Nilai-nilai dan Etika Kepemimpinan Pendidikan dengan Pendekatan Soft System Methodology. Prosiding Seminar Nasional Pendidikan Meningkatkan Layanan Guru dan Kepala Sekolah dalam Penumbuhan Budi Pekerti, Jurusan Administrasi Pendidikan Fakultas Ilmu Pendidikan Universitas Negeri Malang, p. 65-84.

[8] Gunawan, I. 2017. Landasan Dasar Pendidikan. Malang: Universitas Negeri Malang, UM Press. 
[9] Gunawan, I. 2018. Pemberdayaan Tenaga Administrasi Sekolah Menengah Pertama Kota Batu: Studi Deskriptif. JAMP: Jurnal Administrasi dan Manajemen Pendidikan, 1(4), 467-471.

[10] Gunawan, I., Triwiyanto, T., \& Kusumaningrum, D. E. 2018. Pendampingan Penulisan Artikel Ilmiah bagi Para Guru Sekolah Menengah Pertama. Abdimas Pedagogi: Jurnal Ilmiah Pengabdian kepada Masyarakat, 1(2), 128135.

[11] Jenkins, B. 2009. What it Takes to be an Instructional? (Online). (https://www.naesp.org/sites/default/files/JF_p34.pdf), diakses 23 Juli 2019.

[12] Kalmanovich-Cohen, H., Pearsall, M. J., \& Christian, J. S. 2018. The Effects of Leadership Change on Team Escalation of Commitment. The Leadership Quarterly, 29(2), 365-371.

[13] Katkat, D. 2014. The Leadership Abilities of the Teachers Procedia - Social and Behavioral Sciences, 116, 38803885.

[14] Kusumaningrum, D. E., Sumarsono, R. B., \& Gunawan, I. 2018a. Empowering the Principal of Boarding HouseBased Junior High School in East Java Province Indonesia. Proceeding 3rd International Conference on Education Management and Administration (CoEMA 2018), Theme: The Challenges of Educational and Technology in Global and Local Era, Published by Atlantis Press, 269, 147-151.

[15] Kusumaningrum, D. E., Sumarsono, R. B., \& Gunawan, I. 2018b. Teachers Empowerment of Pesantren-Based Junior High School East Java Province Indonesia. Journal of Social Sciences and Humanity Studies, 4(3), 29-33.

[16] Kusumaningrum, D. E., Sumarsono, R. B., \& Gunawan, I. 2019. Budaya Sekolah dan Etika Profesi: Pengukuran Pemberdayaan Sumber Daya Manusia Sekolah dengan Pendekatan Soft System Methodology. JAMP: Jurnal Administrasi dan Manajemen Pendidikan, 2(3), 90-97.

[17] Leavitt, H. J. 2016. Managerial Psychology. Chicago: University of Chicago Press.

[18] Özarall, N. 2015. Linking Empowering Leader to Creativity: The Moderating Role of Psychological (Felt) Empowerment, (Online), International Conference on Leadership, Technology and Innovation Management, Procedia - Social and Behavioral Sciences, hlm. 447-454, (http://www.sciencedirect.com), diakses 13 Oktober 2015.
[19] Patterson, J. L. 1993. Leadership for Tomorrow's Schools. Alexandria: Association for Supervision and Curriculum Development.

[20] Pertiwi, A. K., Cahyani, S. S. A., Diana, R. C., \& Gunawan, I. 2018. Analisis Interaksi Simbolik Kyai dan Santri dalam Perspektif Kepemimpinan Berbasis Nilai dan Etika. JMSP: Jurnal Manajemen dan Supervisi Pendidikan, 2(3), 185191.

[21] Polat, S. 2011. The Level of Faculty Members' Spiritual Leadership (SL) Qualities Display According to Students in Faculty of Education. Procedia - Social and Behavioral Sciences, 15, 2033-2041.

[22] Rukmana, N. 2014. Etika dan Integritas Solusi Persoalan Bangsa. Tangerang Selatan: SBM Publishing.

[23] Sudayat, A. T., Ulfatin, N., \& Sobri, A. Y. 2014 Pemberdayaan dan Pengembangan Sumber Daya Manusia pada Sekolah Inklusi. Ilmu Pendidikan, 41(2), 109-115.

[24] Sultoni, Gunawan, I., \& Rosalinda, T. N. 2018. Pengaruh Pembentukan Tim dan Kepemimpinan Spiritual terhadap Motivasi Diri Mahasiswa. MSP: Jurnal Manajemen dan Supervisi Pendidikan, 2(3), 210-216.

[25] Sultoni, Gunawan, I., \& Rosalinda, T. N. 2018a. Pengaruh Pembentukan Tim dan Kepemimpinan Spiritual terhadap Motivasi Diri Mahasiswa. JMSP: Jurnal Manajemen dan Supervisi Pendidikan, 2(3), 210-216.

[26] Taylor, M., Goeke, J., Klein, E., Onore, C., \& Geist, K. 2011. Changing Leadership: Teachers Lead the Way for Schools that Learn. Teaching and Teacher Education, 27(5), 920-929.

[27] Whittington, J. L., Pitts, T. M., Kageler, W. V., \& Goodwin, V. L. 2005. Legacy leadership: The leadership wisdom of the Apostle Paul. The Leadership Quarterly, 16(5), 749770

[28] Wills, G. 2016. Principal Leadership Changes and their Consequences for School Performance in South Africa. International Journal of Educational Development, 51, 108-124.

[29] Yi-Chen, C., \& Li, C. I. 2013. Assessing the Spiritual Leadership Effectiveness: The Contribution of Follower's Self-Concept and Preliminary Tests for Moderation of Culture and Managerial Position. The Leadership Quarterly, 24(1), 240-255. 